This item was submitted to Loughborough's Research Repository by the author.

Items in Figshare are protected by copyright, with all rights reserved, unless otherwise indicated.

\title{
Understanding and defining institutions: The contribution of Francesco Gual [book review]
}

PLEASE CITE THE PUBLISHED VERSION

https://doi.org/10.1080/1350178X.2017.1389006

\section{PUBLISHER}

Taylor \& Francis (Routledge) @ Geoffrey M. Hodgson

\section{VERSION}

AM (Accepted Manuscript)

\section{PUBLISHER STATEMENT}

This work is made available according to the conditions of the Creative Commons Attribution-NonCommercialNoDerivatives 4.0 International (CC BY-NC-ND 4.0) licence. Full details of this licence are available at: https://creativecommons.org/licenses/by-nc-nd/4.0/

\section{LICENCE}

CC BY-NC-ND 4.0

\section{REPOSITORY RECORD}

Hodgson, Geoffrey M.. 2019. "Understanding and Defining Institutions: The Contribution of Francesco Gual [book Review]”. figshare. https://hdl.handle.net/2134/35763. 


\title{
Understanding and Defining Institutions: The Contribution of Francesco Guala
}

\author{
Geoffrey M. Hodgson \\ University of Hertfordshire, UK.
}

Reviewing Francesco Guala (2016) Understanding Institutions: The Science and Philosophy of Living Together (Princeton and London: Princeton University Press).

In the last 40 years, the study of the nature and role of institutions has moved to the forefront of the social sciences. Numerous empirical studies from several academic disciplines have shown how institutions can have major effects on economic and social outcomes. These enquiries have often used tools such as econometrics, game theory and agent-based models.

But while models and techniques have developed enormously, less attention has been given to improving greater conceptual precision over the meaning of basic concepts - including the term institution. Such analytical and definitional tasks have been neglected. As Brian Epstein (2015) has emphasized, social scientists tend to avoid the 'what is it?' questions concerning the nature of the basic entities and structures in the socio-economic world.

In this context, the book by Francesco Guala on Understanding Institutions is extremely valuable. It makes a major contribution to our understanding of what institutions are, and it carries important implications for future institutional research.

His book bypasses some prominent definitional entanglements that have encumbered research in the past. For example, the recurring assertion that 'organizations are not institutions' does not figure in Guala's book. This misleading claim was largely based on some ambiguous passages in the influential writings of Douglass North, but it was once directly rebutted by North himself (Hodgson 2006, 2015a, 2017). By his analysis and by illustrative examples, Guala implies that organizations are institutions as well. Perhaps, hopefully, we have moved on from those earlier and fruitless disputes. Instead, we face the challenging and vital task of understanding the general nature of institutions and the important differences between particular types.

As Guala acknowledges in his book, part of his argument was developed jointly with Frank Hindriks (Hindricks and Guala 2015). Their work criticizes the major contribution to the ontology of institutions by John R. Searle $(1995,2005)$ and develops an alternative. Nevertheless, their debt to the pioneering contributions by the American philosopher is clear.

Guala's book is very clearly written and well-structured. Its accessible prose makes it ideal as an introductory text. By reviewing several complex problems and offering solutions it will help further constructive debate and theoretical development.

The introduction of the book provides a useful overview. In the first chapter, Guala notes that the most prominent definition of an institutions is in terms of rules, as in North's (1990) 'rules of the game', and in similar formulations by several other leading authors. But Guala points out that this formulation does not explain why people are motivated to follow rules. 
In Chapter 2 Guala shows how game theory places individual incentives in interactive settings. When there are stable equilibria, individual interactions result in an established rule. Accordingly, stable rules exist and are followed because they are shared, stable solutions to coordination problems among individuals. In Chapter 3 Guala applies and develops his approach by addressing the institution of money, which was also one of Searle's (1995) favourite cases. Guala argues that money is understandable in terms of his 'rules-inequilibrium' formulation.

The 'rules-in-equilibrium' argument is further buttressed in Chapter 4, which considers 'correlated equilibria' that are established by individuals following rules. Hence institutional conventions involve both behavioural regularities and rules. Chapter 5 criticizes Searle's famous distinction between 'constitutive' and 'regulative' rules. Guala argues that the distinction ultimately breaks down, and that constitutive rules can be derived from regulative rules.

Chapter 6 addresses the issue of normativity. Again, in part, this responds to Searle, who argued that institutional rules have an important deontic dimension. Guala proposes that deontic powers may be represented as costs that modify individual incentives in strategic games. Chapter 7 considers how we form expectations concerning the behaviour of others.

Chapter 8 argues that, contrary to several other philosophers (including Searle), many institutions do not require joint or collective intentions to be sustainable. The focus on collective intentionality in the writings of Searle and others is dismissed as both controversial and unnecessary. Instead, institutions involve interacting individuals identifying problems and searching for solutions.

Chapter 9 considers how many institutions involve reflexive feedback loops, which can be captured by game-theoretic models. Following on from this, Chapter 10 critically addresses Ian Hacking's (1999) view that social kinds are different from natural kinds because the former involve interactions between the observer and the phenomena. The distinction, it is argued, breaks down in some cases and 'interactive kinds' are as real as natural phenomena.

Chapter 11 addresses 'the dependence thesis', according to which institutional entities depend for their existence on our representations. In Chapter 12 Guala argues that the dependence thesis is false. In this way he rescues a form of philosophical realism. He argues that the nature of an institution is determined by its function, not what people think about it. For example, people use money with little knowledge or understanding of many of the legal or financial rules involved.

Chapter 13 considers how institutions can be changed. Marriage is used as an illustrative example. Despite its long endurance, marriage has evolved in meaning and application. Chapter 14 ends the book, arguing that the enduring character of an institutional type is founded on the enduring similarity of its functions. Hence institutions such as marriage can be changed to include same-sex unions, without overturning the meaningfulness of marriage itself, as long as same-sex marriages perform key functions similar to those of heterosexual marriages.

In sum, Guala synthesises the 'rules' and 'equilibria' understanding of institutions, removes the dichotomy between constitutive and regulatory rules, shows that institutions do not necessarily involve collective intentionality, suggests that institutional rules are not necessary deontic, and defends ontological realism by rebutting the notion that institutional entities depend for their existence on our representations of them. These are major claims. If they can withstand critical interrogation, then they are each path-breaking in importance.

But, without detracting from the huge achievement of Guala's book, I think there are some problems with parts of his argument. The first concerns the consistency and scope of his basic 
conception of an institution. While Guala accepts that nonhuman 'animals do not have institutions' (p. 52) his rules-in-equilibrium conception of an institution would seem to apply to populations of entities way beyond the human species, including many living things from nonhuman primates to bacteria, some autopoietic or self-organising processes in chemistry and biology, and groups of interacting robots.

Consequently, some essential human element is missing. If institutions are to be confined to the human species, then some uniquely human attribute - such as a developed morality or sophisticated language - must be identified as part of the nature of an institution.

Searle's answer to this problem may lie in his insistence on the deontic character of the particular rules. Dogs and robots can learn rules, but they seem to avoid deontic matters of duty or morality. But as Guala points out, some rules in the human sphere are learned and followed out of convenience, rather than because of duty or moral obligation. Such rules include the traffic convention of driving on the right (or left) of the road, and the rules of language. Because these seem to be exceptions, strong deontic features are not universal among human institutions, despite issues of justice and duty being widespread and prominent elsewhere. Consequently, it seems that neither Guala nor Searle have successfully established criteria that encompass all institutions and confine them to the human species.

A second problem concerns the nature of human agents and how rules are established. In the opening chapter of the book, Guala makes much use of simple game theory to establish key parts of his argument. His standard version of game theory assumes agents acting as if they are fully aware of all the options in front of them, and of the consequences of their choice of actions, given the choices of others. It is also assumed that players act as if they believe that others are similarly aware of the structure and payoffs, and believe that others will also act to maximise their payoffs in the game. In other words, Guala here adopts the standard rationality and common-knowledge assumptions of classical game theory.

But, as his argument proceeds, he moves away from some of these core assumptions. In some passages in later parts of the book, Guala argues that institutions do not depend for their existence upon our beliefs or representations. Guala (2016, pp. 172-5) accepts that 'social life often consists of a series of practices rather than conscious decisions based on explicit theoretical deliberation ... There are plenty of examples of paradigmatic institutions that exist quite independently of anyone holding any correct or incorrect theory of their functioning.' This would suggest that game theory, while valuable, has some limits as a tool to understand institutions. Yet game theory is the principal means by which the rules-in-equilibrium approach is established.

The third problem in Guala's book is its apparent conflation of two different tasks - of providing a taxonomic definition of a type, and of identifying and understanding its essential features. In some passages Guala writes as if he is defining institutions, alongside the explicit project of understanding them. Yet taxonomic definition of a kind must precede the task of trying to understand that kind, otherwise we are unsure of what entities we are trying to understand. Of course, emerging understandings or new evidence may cause us to adapt a taxonomic definition, but that does not undermine the temporal priority of taxonomy.

We need to address the nature and derivation of taxonomic definitions. Taxonomic definitions are different from mathematical definitions because the latter involve stipulation of meaning, where a word or symbol may be used with less regard for previously-established meanings. Writers addressing taxonomic definitions stress the importance of parsimony and of sufficient concordance with established usages of a term (Malthus 1827, Robinson 1950, Belnap 1993). 
Consider the taxonomic definition of a mammal. Classically a mammal is defined as an animal that suckles its young (although the increasing burden of fossil evidence has modified this definition (Hodgson 2015b)). In any case, the definition of a mammal is highly parsimonious. No adopted definition attempts to describe mammals in more detail, or to list a host of important common features. Omitted are crucial shared characteristics, such as being warm-blooded vertebrates with four limbs, or having lungs and brains. The suckling criterion is sufficient to demarcate, and hence it can serve adequately as a taxonomic definition.

Definitions in biology can often be highly parsimonious because the evolution of species is hierarchical or tree-like: when a new biological species emerges it diverges from the others, and its members rarely if ever inter-breed across species boundaries. Hence it is typically sufficient to identify distinguishing features that emerge at the base of a branch of the tree of evolutionary descent.

By contrast, in the social sciences, not only individuals but whole species can meld together, creating hybrids. For example, the English language is a fusion of multiple language types, with Latin, Germanic and other separate roots. Some prominent legal systems involve combinations of common and civil law. And so on.

Given such complications, where can we turn for help? In his Topica, Aristotle wrote: 'A definition is an account that signifies the essence'. Note that he used the verb 'signify', rather than 'describe' or 'explain'. We need a sign: we have to find a common feature that signals the nature of the beasts, and it is sufficient to demarcate them from the others. Taxonomic definitions identify the minimum number of essential properties that are sufficient to demarcate entities of that kind from other entities.

This leads to the question whether equilibria should be part of the taxonomic definition of an institution. Being outcomes of individual interactions, equilibria are secondary to the relational framework that generates their possibility. In game theory, rules make up the game form, and an equilibrium is a possible game outcome. But if the equilibrium concept is vital to understand how institutions work, this does not mean that it has to be part of the taxonomic definition.

Crafters of definitions should also acknowledge the weight of customary meanings of words. The depiction of institutions as shared systems of rules has near-customary status in the academic literature on the topic (North 1990, Ostrom 1990, Knight 1992, Crawford and Ostrom 1995, Mantzavinos 2001).

I proposed elsewhere that the definition of institutions in terms of integrated systems of rules that structure social interactions (where the term 'rule' also requires definition - see below) gives us a rough but useful demarcation criterion to distinguish institutions from other social phenomena (Hodgson 2006, 2015a).

This definition effectively establishes institutions as sub-category of social structure, which is another important concept in social science. Typically, social theorists broadly define social structures as sets of relations between individuals (Porpora 1987). Consequently, all institutions are social structures, but not all social structures are institutions. For example, social structures include the demographic or gender structure of a society, but these are not essentially systems of rules, and hence they are not institutions. The 'shared systems of rules' definition of an institution does the job of excluding these important non-institutional phenomena: it is a non-trivial demarcation device.

Given that institutions are systems of rules, we need to clarify the nature of a rule. As a very simple approximation, we can understand a rule as a culturally-learned and mutually understood injunction or disposition, that in circumstances $X$ do $Y$. In turn, 'do $Y$ ' must be 
interpreted broadly, to include prohibitions as well as obligations (Crawford and Ostrom 1995). Rules must also be potentially codifiable so that breaches can become subjects of discourse.

The rules that make up institutions must be more than mere declarations by some authority. As Elinor Ostrom $(1990,2000)$ insisted, they must be rules in actual or potential use in a community. Even if the rule is never violated it must act as a real constraint. There must also be some commitment in the community to follow the rule (Gilbert 1989). Rules include norms of behaviour and social conventions, as well as legal or formal rules.

Several points follow. First, the 'systems of rules that structure social interactions' definition of an institution performs the taxonomic task of identifying institutions at least as well as the 'rules in equilibria' formulation. But note that this 'systems of rules' definition depends on a more restrictive notion of 'rule' than that found in Guala's book.

With this more restrictive notion of a rule it is possible to confine institutions to the human domain, thereby excluding non-human animals and robots. Suitably refined concepts of rulecodifiability and cultural learning would suggest this.

Furthermore, the problem of explaining why people follow rules is dealt with by defining rules as dispositions. By this definition, declarations or edicts are not rules unless they become ingrained in the habits or other dispositions of a significant number of people. The additional, 'in equilibrium' attribute of an institution becomes redundant, not only for the taxonomic definition but also for a general description of its core institutional features.

This approach would find rapport with the latter part of the book, where Guala downplays the role of 'conscious decisions based on explicit theoretical deliberation'. A habit-based conception of action could help fill this gap (James 1890, Veblen 1914, Dewey 1922, Joas 1996, Hodgson 2004).

The richness of Guala's book is underlined rather than undermined by these critical comments. He consolidates an important argument and raises additional questions that help us to move further forward. This is a great book, which should be read by every social scientist who wants to understand institutions.

\section{References}

Belnap, Nuel D. (1993) 'On Rigorous Definitions', Philosophical Studies, 72(2/3), December, pp. 115-46.

Crawford, Sue E. S. and Ostrom, Elinor (1995) 'A Grammar of Institutions', American Political Science Review, 89(3), September, pp. 582-600.

Dewey, John (1922) Human Nature and Conduct: An Introduction to Social Psychology (New York: Holt).

Epstein, Brian (2015) The Ant Trap: Rebuilding the Foundations of the Social Sciences (Oxford and New York: Oxford University Press).

Gilbert, Margaret (1989) On Social Facts (London and New York: Routledge).

Guala, Francesco (2016) Understanding Institutions: The Science and Philosophy of Living Together (Princeton and London: Princeton University Press).

Hacking, Ian (1999) The Social Construction of What? (Cambridge, MA: Harvard University Press). 
Hindriks, Frank and Guala, Francesco (2015) 'Institutions, Rules, and Equilibria: A Unified Theory', Journal of Institutional Economics, 11(3), September, pp. 459-480.

Hodgson, Geoffrey M. (2004) The Evolution of Institutional Economics: Agency, Structure and Darwinism in American Institutionalism (London and New York: Routledge).

Hodgson, Geoffrey M. (2006) 'What Are Institutions?' Journal of Economic Issues, 40(1), March, pp. 1-25.

Hodgson, Geoffrey M. (2015a) Conceptualizing Capitalism: Institutions, Evolution, Future (Chicago: University of Chicago Press).

Hodgson, Geoffrey M. (2015b) 'On Defining Institutions: Rules versus Equilibria', Journal of Institutional Economics, 11(3), September 2015, pp. 499-505.

Hodgson, Geoffrey M. (2017) 'Introduction to the Douglass C. North Memorial Issue', Journal of Institutional Economics, 13(1), March, pp. 1-23.

James, William (1890) The Principles of Psychology, 2 vols (New York and London: Holt and Macmillan).

Joas, Hans (1996) The Creativity of Action (Chicago: University of Chicago Press).

Knight, Jack (1992) Institutions and Social Conflict (Cambridge: Cambridge University Press).

Mantzavinos, Chris (2001) Individuals, Institutions and Markets (Cambridge and New York: Cambridge University Press).

Malthus, Thomas Robert (1827) Definitions in Political Economy (London: John Murray).

North, Douglass C. (1990) Institutions, Institutional Change and Economic Performance (Cambridge and New York: Cambridge University Press).

Ostrom, Elinor (1990) Governing the Commons: The Evolution of Institutions for Collective Action (Cambridge: Cambridge University Press).

Ostrom, Elinor (2000) 'Collective Action and the Evolution of Social Norms', Journal of Economic Perspectives, 14(3), Summer, pp. 137-58.

Porpora, Douglas V. (1987) The Concept of Social Structure (New York and London: Greenwood Press).

Robinson, Richard (1950) Definition (Oxford: Clarendon Press).

Searle, John R. (1995) The Construction of Social Reality (London: Allen Lane).

Searle, John R. (2005) 'What is an Institution?' Journal of Institutional Economics, 1(1), June, pp. 1-22.

Veblen, Thorstein B. (1914) The Instinct of Workmanship, and the State of the Industrial Arts (New York: Macmillan). 